\title{
Feeding behavior and performance of sheep fed cactus pear in substitution of corn ${ }^{1}$
}

\section{Roberto Germano Costa ${ }^{2}$, Israel Hernandéz Treviño², Geovergue Rodrigues de Medeiros ${ }^{3}$, Ariosvaldo Nunes de Medeiros ${ }^{2}$, Severino Gonzaga Neto², Paulo Sérgio de Azevedo², Tiago Ferreira Pinto ${ }^{3}$}

\author{
${ }^{1}$ Project funded by IDR/Sisal - Valente, BA, Brasil. \\ 2 Departamento de Zootecnia, Universidade Federal da Paraíba, Areia, PB, Brasil. \\ ${ }^{3}$ Departamento de Produção Animal, Instituto Nacional do Semiárido, Campina Grande, PB, Brasil.
}

\begin{abstract}
The objective of this study was to evaluate the feeding behavior and performance of Santa Ines sheep subjected to different levels of substitution of corn by cactus pear in the diet. Forty-five non-castrated male Santa Inês sheep with initial live weight of $27.50 \pm 0.48 \mathrm{~kg}$ were distributed in a completely randomized design with five treatments $(0,70,140,210$ and $280 \mathrm{~g} / \mathrm{kg} \mathrm{DM}$ ) and nine replicates. Dry matter and neutral detergent fiber intakes showed quadratic behavior. Times spent eating, ruminating and total ruminating chews showed increasing linear behavior, while the idle time decreased with increasing amounts of dietary cactus. The feeding efficiency $(\mathrm{g} \mathrm{DM} / \mathrm{h})$ increased linearly, while differences in rumination efficiency of the $\mathrm{DM}(\mathrm{g} \mathrm{DM} / \mathrm{h}) ; \mathrm{NDF}$ intake efficiency $(\mathrm{g} \mathrm{NDF} / \mathrm{h})$ and NDF rumination efficiency $(\mathrm{g} \mathrm{NDF} / \mathrm{h})$ were not significant. There was no significant effect for the number of ruminated boli and number of ruminating chews per bolus. The number of chews per day increased linearly. These results indicate that cactus pear in substitution of corn had no influence on the feeding behavior of feedlot sheep.
\end{abstract}

Key Words: feeding efficiency, ruminating chews, rumination, semiarid

\section{Introduction}

In the confinement of sheep, there is optimization in the use of concentrates to increase the energy density of diets, where corn is one of main ingredients used as energy source. In the Brazilian semiarid region, much of this corn is imported from producing regions, and typically reaches high values, affecting production costs.

One alternative would be to use an energy source of lower cost and locally available, such as cactus pear (Opuntia ficus indica), which has a high water-holding capacity and is adapted to the environmental conditions of semiarid areas (Melo et al., 2003; Tegegne et al., 2007).

In nutritional terms, cactus pear is rich in energy, minerals and vitamin A (Felker, 2001; Tegegne, 2003; Misra et al., 2006) and presents high digestibility and effective degradability rates of dry matter, crude protein and neutral detergent fiber, as reported by Teixeira et al. (1999), Menezes et al. (2010) and Costa et al. (2012).

On the other hand, cactus pear, regardless of genus, has a low fiber content, on average, $26 \%$ of NDF, which may be an important factor in the modification of the eating behavior of animals by reducing the chewing activity and therefore decreasing the secretion of saliva, changing the rumen $\mathrm{pH}$ and affecting animal performance. Therefore, Santos et al. (1998) and Ferreira (2005) recommend its association with roughages as sources of fiber for the neutral detergent fiber correction.

Studies that evaluate the feeding behavior of sheep fed cactus pear are important due to the specific nutritional characteristics of this forage. These studies represent an important tool in assessing diets, since their results allow for adjusting the feeding management to obtain the best animal productive response (Van Soest, 1994; Mendonça et al., 2004; Cardoso et al., 2006; Carvalho et al., 2006) and generate information to assist in decision-making by technicians and farmers with regard to the use of cactus pear in substitution of corn in finishing feedlot sheep.

The objective of this study was to evaluate the performance and feeding behavior of sheep fed increasing levels of cactus pear (Opuntia ficus indica Mill) in substitution of corn.

\section{Material and Methods}

The experiment was conducted at the Experimental Station of São João do Cariri-PB, which belongs to Universidade Federal da Paraíba, located at the Cariri micro 
region, eastern state of Paraiba (Brazil), at coordinates $7^{\circ} 29^{\prime} 34^{\prime \prime} \mathrm{S}$ and $36^{\circ} 41^{\prime} 53^{\prime \prime} \mathrm{W}$. According to the Köppen classification, the climate is Bsh'W (hot semiarid climate), with average annual temperatures around $26{ }^{\circ} \mathrm{C}$, annual rainfalls of $395 \mathrm{~mm}$ and relative humidity around $68 \%$.

In this study we used 45 Santa Inês young sheep with initial live weight (LW) of $27.50 \pm 0.48 \mathrm{~kg}$, which were confined in individual stalls with dimensions of $2 \times 2 \mathrm{~m}$, with dirt floor equipped with drinking and feeding troughs, where the animals received the experimental diets. Animals were weighed, identified, and had internal parasites removed at the beginning of the experiment.

The ingredients used to compose the experimental diets were Tifton hay (Cynodum sp), soybean meal, corn, wheat bran, limestone, mineral salt and cactus pear (Table 1). The cactus pear was manually cut into slices of approximately $5 \mathrm{~cm}^{2}$. The diets (Table 2) were formulated to meet the requirements of sheep with $25 \mathrm{~kg}$ of LW for a daily gain of $250 \mathrm{~g} /$ day (NRC, 1985).

The treatments consisted of replacing corn by cactus pear (Opuntia ficus indica Mill) at increasing levels: 0, 70, 140,210 and $280 \mathrm{~g} / \mathrm{kg}$ DM. The experimental diets were offered in two daily meals $(50 \%$ in the morning, at 7:00 a.m. and $50 \%$ in the afternoon, at 4:00 p.m.) in the form of complete mixture. The amount of food offered and the leftovers were weighed daily to calculate the voluntary intake, allowing for $10 \%$ of leftovers. Water was provided ad libitum and water troughs were monitored every day.

Measurements of dry matter (DM), mineral matter $(\mathrm{MM})$, crude protein $(\mathrm{CP})$ and ether extract (EE) were performed according to methodology described by Silva \& Queiroz (2002). Cell wall fractions, neutral detergent fiber (NDF) and acid detergent fiber (ADF) were determined by the methodology described by Van Soest et al. (1991). ANKOM Technology ${ }^{\circledR}$ equipment was used. The bags used for analysis were adapted, using polypropylene bags (nonwoven fabric, basis weight $100 \mathrm{~g} / \mathrm{m}^{2}$ ). Total carbohydrates (TC) were determined according to Sniffen et al. (1992) using the equation $\mathrm{TC}=100-(\% \mathrm{CP}+\% \mathrm{EE} \%+\mathrm{MM})$ and nonfibrous carbohydrates were determined according to Hall et al. (1999) using the equation $\mathrm{NFC}=\% \mathrm{TC}-\% \mathrm{NDFp}$.
To evaluate the apparent digestibility coefficients, feces were collected directly from the rectal ampulla during 5 days of collection of each experimental period, taking a sample of approximately $10 \%$ of the excreted volume and at the end of the collection period, the fecal samples were homogenized, making a composite sample for the subsequent laboratory analyses. Samples of feces, feed and leftovers were incubated in situ in nonwoven-fabric bags, (TNT $-100 \mathrm{~g} / \mathrm{m}^{2}$ ) for a period of 240 hours (Casali et al., 2008). The material remaining from incubation was subjected to extraction with acid detergent, whose residue was considered iADF. Fecal excretion was estimated through the relation between consumption and fecal concentration.

The total digestible nutrient contents (TDN) of feeds were calculated according to the equation proposed by Weiss (1999), where TDN $(\%)=(\% \mathrm{CPd}+\% \mathrm{NDF} p \mathrm{~d}+$ $\% \mathrm{NFCd}+(\% \mathrm{EEd} \times 2.25)-7(\mathrm{CPd}$, digestible crude protein; NDFcpd, digestible neutral detergent fiber corrected for protein; NFCd, digestible non-fibrous carbohydrate; EEd, digestible ether extract). The digestible energy (DE) was estimated as DE $(\mathrm{Mcal} / \mathrm{kg})=0.04409 \times \mathrm{TDN}(\%)$. The conversion of DE to ME was estimated as $\mathrm{DE} \times 0.82$.

Observations concerning the feeding behavior of animals were performed over a period of 24 hours from 07:00 a.m. to 07:00 a.m. of the next day. Data were collected by the scan sampling method, according to Martin \& Bateson (1993). Observations were recorded in previously prepared spreadsheets.

The average idle, rumination and eating times were analyzed. Idling was determined as the absence of mandibular movement. The night observation of animals was performed by using fluorescent lighting.

To evaluate the ruminating chew, five animals of each treatment were used. Two periods for the rumination observation were evaluated, the first being from 10:00 p.m. to midnight and the second from 4:00 a.m. to 6:00 a.m., determining the number of ruminating chews and the time spent (in seconds) in the rumination of each ruminate bolus using a digital stopwatch. Chewing was calculated by three times of 15 seconds each, in which the average was

Table 1 - Nutritional characteristics of the diet ingredients on a dry matter basis $(\mathrm{g} / \mathrm{kg} \mathrm{DM})$

\begin{tabular}{lcccccccccccc}
\hline Ingredients & DM & OM & MM & CP & EE & NDF & NDFp & ADF & TC & NFC & TDN & ME \\
\hline Cactus pear & 108.3 & 871.8 & 118.1 & 39.5 & 16.5 & 311.6 & 298.1 & 216.8 & 825.8 & 530.4 & 608.3 & 2.20 \\
Ground corn & 885.1 & 984.5 & 15.4 & 87.7 & 35.7 & 114.4 & 80.6 & 42.4 & 861.2 & 780.6 & 855.8 & 3.09 \\
Soybean meal & 892.5 & 929.8 & 70.1 & 482.0 & 23.2 & 145.5 & 83.5 & 109.6 & 424.7 & 341.2 & 756.6 & 2.74 \\
Wheat bran & 878.8 & 913.0 & 56.9 & 161.2 & 35.5 & 453.8 & 424.9 & 134.1 & 746.4 & 321.5 & 644.4 & 2.33 \\
Tifton hay & 909.9 & 909.6 & 70.3 & 86.8 & 14.4 & 791.7 & 744 & 392.1 & 828.5 & 84.5 & 481.6 & 1.74 \\
\hline
\end{tabular}

DM - dry matter; OM - organic matter; MM - mineral matter; CP - crude protein; EE - ether extract; NDF - neutral detergent fiber; NDFp - neutral detergent fiber corrected for protein; ADF - acid detergent fiber; TC - total carbohydrates; NFC - non-fibrous carbohydrates; TDN - total digestible nutrients; ME - metabolizable energy (Mcal/kg of DM). 
Table 2 - Composition of ingredients in the diets $(\mathrm{g} / \mathrm{kg} \mathrm{DM})$ according to the levels of cactus pear substitution

\begin{tabular}{lccccc}
\hline \multirow{2}{*}{ Ingredients } & \multicolumn{5}{c}{ Substitution levels $(\mathrm{g} / \mathrm{kg})$} \\
\cline { 2 - 6 } & 0 & 70 & 140 & 210 & 280 \\
\hline Cactus pear & 0.00 & 70.0 & 140.0 & 210.0 & 280.0 \\
Ground corn & 280.0 & 210.0 & 140.0 & 70.0 & 0.00 \\
Soybean meal & 176.0 & 176.0 & 176.0 & 176.0 & 176.0 \\
Wheat bran & 114.0 & 114.0 & 114.0 & 114.0 & 114.0 \\
Tifton hay & 400.0 & 400.0 & 400.0 & 400.0 & 400.0 \\
Mineral salt & 15.0 & 15.0 & 15.0 & 15.0 & 15.0 \\
Limestone & 15.0 & 15.0 & 15.0 & 15.0 & 15.0 \\
Diet composition (g/kg DM) $)$ & & & & & \\
Dry matter & 894.6 & 593.4 & 444.0 & 354.6 & 295.2 \\
Organic matter & 907.2 & 899.3 & 891.4 & 883.5 & 875.6 \\
Mineral matter & 51.1 & 58.4 & 65.6 & 72.8 & 80.0 \\
Crude protein & 162.4 & 159.1 & 155.7 & 152.3 & 148.9 \\
Ether extract & 23.8 & 22.5 & 21.1 & 19.8 & 18.5 \\
Neutral detergent fiber & 426.0 & 439.8 & 453.6 & 467.4 & 481.2 \\
NDFp & 383.3 & 398.5 & 413.7 & 428.9 & 444.2 \\
Acid detergent fiber & 203.2 & 215.4 & 227.7 & 239.9 & 252.1 \\
Total carbohydrates & 762.7 & 760.0 & 757.6 & 755.1 & 752.6 \\
Non-fibrous carbohydrates & 379.4 & 361.5 & 343.9 & 326.2 & 308.4 \\
Total digestible nutrients & 638.8 & 621.5 & 604.2 & 586.9 & 569.5 \\
Metabolizable energy ${ }^{1}$ & 2.30 & 2.24 & 2.18 & 2.12 & 2.05 \\
\hline
\end{tabular}

NDFp - neutral detergent fiber corrected for protein.

${ }^{1} \mathrm{Mcal} / \mathrm{kg}$ of DM.

determined and then multiplied by four, thus generating the chewing time per minute.

To calculate the dry matter (DM), crude protein (CP) and neutral detergent fiber (NDF) intake, twenty-five days after starting the experiment and for seven days, samples of food and leftovers were collected, weighed, identified and stored in a freezer at $-15^{\circ} \mathrm{C}$ for further analysis. At the end of this assay, the leftovers were homogenized and turned into a single composite sample per animal. Subsequently, the samples were pre-dried in an oven with forced ventilation at $55^{\circ} \mathrm{C}$ for 72 hours and ground in a Wiley knife mill with $1 \mathrm{~mm}$ mesh for subsequent determinations.

The following relationships (feeding and rumination efficiencies as a function of the DM and NDF intake, respectively), adapted from Bürger et al. (2000), were calculated:

$$
\begin{gathered}
\mathrm{FE} \text { of DM }=\mathrm{DMI} / \mathrm{FT}(\mathrm{g} \mathrm{DM} / \mathrm{h}), \\
\mathrm{FE} \text { of } \mathrm{NDF}=\mathrm{NDFI} / \mathrm{FT}(\mathrm{g} \mathrm{NDF} / \mathrm{h}), \\
\mathrm{RUE} \text { of DM }=\mathrm{DMI} / \mathrm{RT}(\mathrm{g} \mathrm{DM} / \mathrm{h}), \\
\mathrm{RUE} \text { of } \mathrm{NDF}=\mathrm{NDFI} / \mathrm{RT}(\mathrm{g} \mathrm{NDF} / \mathrm{h}),
\end{gathered}
$$

where: $\mathrm{DM}=$ dry matter; FT (h/day) = feeding time; RT $(\mathrm{h} /$ day $)=$ total rumination time; DMI $=$ dry matter intake $(\mathrm{kg} \mathrm{DM} /$ day); NDFI = NDF intake (NDF kg/day).

The number of ruminated boli (NRB), chews per day (NCD) and ruminating chews per bolus (NRCB) were also determined, according to Polli et al. (1996).

A completely randomized experimental design with five treatments and nine replications was applied, using initial weight as covariate. Data were submitted to analysis of variance, using the least square method. The following mathematical model was used:

$$
\mathrm{Y}_{\mathrm{ij}}=\mu+\mathrm{T}_{\mathrm{i}}+\beta\left(\mathrm{x}_{\mathrm{ij}}-\overline{\mathrm{x}}\right)+\varepsilon_{\mathrm{ij}}
$$

where: $Y_{i j}=$ effect of $i$-th treatment evaluated on the $j$-th animal; $\mu=$ observed mean; $T_{i}=$ effect of treatment of the i-th order, with $\mathrm{i}=0,70,140,210$ and $280 \mathrm{~g} / \mathrm{kg} \mathrm{DM}$ of replacement of corn with cactus pear; $\left(\beta\left(\mathrm{x}_{\mathrm{ij}}-\overline{\mathrm{x}}\right)=\right.$ effect of the covariate initial weight; and $\varepsilon_{\mathrm{ij}}=$ random error.

Besides the analysis of variance, regression analysis was also performed, according to the level of cactus pear in the diet. The criteria used to select the equations were the biological behavior, the determination coefficient $\left(\mathrm{r}^{2}\right)$ and significance for the regression parameters, obtained by the t-test for the 5\% probability level. Statistical analyses were performed with the aid of the SAEG software (Sistema para Análises Estatísticas e Genéticas, version 9.1).

\section{Results and Discussion}

The fresh matter (FM) intake increased linearly $(\mathrm{P}<0.01)$ as the cactus pear levels in the diet were increased, ranging from 1.59 to $4.76 \mathrm{~kg}$ in 24 hours for diets with 0 and $280 \mathrm{~g} / \mathrm{kg}$ DM of cactus pear, respectively (Table 3 ).

Diets containing cactus pear had higher moisture content and therefore, sheep increased intake to meet their daily requirements of dry matter intake and energy. It is noteworthy that although the diets were offered as a complete ration, sheep initially selected cactus pear, and then they consumed Tifton hay and concentrate. Cactus pear is highly palatable and large amounts can be voluntarily consumed.

The dry matter intake (DMI) showed quadratic behavior $(\mathrm{P}<0.05)$ with increasing cactus pear levels in diets. The maximum point was $152.6 \mathrm{~g} / \mathrm{kg} \mathrm{DM}$ of inclusion of cactus pear, in which the dry matter intake reached $1.49 \mathrm{~kg} /$ day. It appears that from $140 \mathrm{~g} / \mathrm{kg}$ of DM of inclusion of cactus pear, the DMI starts to decrease, reaching $1.34 \mathrm{~kg} / \mathrm{day}$ in the diet with $280 \mathrm{~g} / \mathrm{kg}$ DM of substitution of corn by cactus pear. This is due to the ruminal fill caused by both the amount of neutral detergent fiber (NDF) intake and the ingestion of water from the cactus pear.

The NDF intake was curvilinear $(\mathrm{P}<0.05)$. The maximum point was $200.6 \mathrm{~g} / \mathrm{kg}$ DM of substitution of corn by cactus pear, providing an estimated intake of $0.639 \mathrm{~kg}$ of $\mathrm{NDF} /$ day. The increase in NDF intake is due to the higher levels of this ingredient in the diets with inclusion of cactus pear. Moreover, the NDF intake expressed in $\mathrm{g}$ of DM/kg of live weight and in $\mathrm{g} /$ metabolic weight increased (Table 3 ). 
The eating and rumination times increased linearly $(\mathrm{P}<0.05)$ with increasing amounts of cactus pear in diets. Thus, the total chewing was also affected, increasing linearly $(\mathrm{P}<0.01)$ (Table 3$)$. These behaviors occur due to the increased NDF levels and, consequently, increased physical volume provided by diets with addition of cactus pear, which required more time spent eating for sheep to meet their nutritional requirements, as reported by Albright (1993) and Lima et al. (2003), who substituted corn by cactus pear to feed dairy cows.

According to Queiroz et al. (2001), the feed intake level influences the rumination time, and large feed intakes increase rumination. Arnaud et al. (2005) reported that the rumination time of dairy cows decreased linearly with the addition of increasing levels of cactus pear.

The idle time decreased linearly $(\mathrm{P}<0.05)$. Each percentage unit of substitution of corn by cactus pear reduced the idle time by $0.0083 \mathrm{~h} /$ day ( 1.386 minutes/day), i.e., with the addition of cactus pear to the diet, sheep spend more time eating and ruminating.

Feeding efficiency as a function of DM intake (FE of $\mathrm{DM})$ reduced linearly $(\mathrm{P}<0.05)$ in response to the longer time spent eating and due to the increased diet NDF contents. This statement was corroborated by the negative correlation between FE of DM and the time eating $(-0.71, \mathrm{P}<0.0001)$.
Van Soest (1994) reports that the feeding efficiency is related to the time devoted to feed consumption and to the specific weight of the feed consumed.

The rumination efficiency as a function of DM (RUE of $\mathrm{DM}$ ) was not significant ( $\mathrm{P}>0.05)$, averaging $185.3 \mathrm{~g}$ $\mathrm{DM} / \mathrm{h}$. Similar results were found for the feeding efficiency as a function of NDF intake (FE of NDF) and rumination efficiency as a function of NDF (RUE of NDF), with averages of 124.7 and $76.3 \mathrm{~g} \mathrm{NDF} / \mathrm{h}$, respectively.

These results demonstrate that the partial or total substitution of corn by cactus pear in the diet of sheep did not decrease the ruminating stimulation of animals due to the fibrousness of diets, which increased with the addition of cactus pear from 426 to $481 \mathrm{~g}$ of NDF between treatments from 0 and $280 \mathrm{~g} / \mathrm{kg} \mathrm{DM}$ of corn substitution, respectively (Table 2). This increase is a result of the higher NDF concentration in cactus pear in relation to corn.

The substitution of corn by cactus pear did not significantly influence $(\mathrm{P}>0.05)$ the number of ruminated boli (NRB) per day and the number of ruminating chews per bolus (NRCB). However, the number of chews per day $(\mathrm{NCD})$ increased linearly $(\mathrm{P}<0.05)$ with the addition of cactus pear, demonstrating that the concentration of dietary NDF stimulated sheep rumination and probably did not increase the passage of feed through the digestive tract (Table 4).

Table 3 - Intake and time spent eating, ruminating and idling by Santa Inês sheep fed cactus pear in substitution of corn

\begin{tabular}{|c|c|c|c|c|c|c|c|c|}
\hline \multirow{2}{*}{ Variable } & \multicolumn{5}{|c|}{ Cactus pear levels ( $\mathrm{g}$ of DM/kg) } & \multirow{2}{*}{$\mathrm{CV}(\%)$} & \multirow{2}{*}{ Regression equation } & \multirow{2}{*}{$\mathrm{r}^{2}$} \\
\hline & 0 & 70 & 140 & 210 & 280 & & & \\
\hline Fresh matter intake $(\mathrm{kg} /$ day $)$ & 1.59 & 2.38 & 3.17 & 3.97 & 4.76 & 19.18 & $\hat{Y}=1.590978+0.0113184 * \mathrm{CP}$ & 0.98 \\
\hline Dry matter intake $\left(\mathrm{g} / \mathrm{LW}^{0.75}\right)$ & 96.50 & 109.16 & 111.93 & 106.93 & 102.10 & 16.93 & $\hat{\mathrm{Y}}=105.32^{\mathrm{ns}}$ & - \\
\hline NDF intake ( $\mathrm{kg} /$ day) & 0.476 & 0.571 & 0.627 & 0.636 & 0.615 & 18.93 & $\hat{\mathrm{Y}}=0.476326+0.001605 * \mathrm{CP}-0.000004 * \mathrm{CP}^{2}$ & 0.99 \\
\hline NDF intake ( $g / k g$ live weight) & 38.80 & 41.27 & 43.75 & 46.22 & 48.70 & 18.37 & $\hat{\mathrm{Y}}=38.805556+0.035335 * \mathrm{CP}$ & 0,69 \\
\hline NDF intake $\left(\mathrm{g} / \mathrm{LW}^{0.75}\right)$ & 16.36 & 17.42 & 18.47 & 19.68 & 20.59 & 18.32 & $\hat{\mathrm{Y}}=16.363111+0.015114 * \mathrm{CP}$ & 0.72 \\
\hline Idle time (h/day) & 11.29 & 10.92 & 10.13 & 9.57 & 9.32 & 14.96 & $\hat{\mathrm{Y}}=11.296222-0.008275 * \mathrm{CP}$ & 0.78 \\
\hline Total chewing time (h/day) & 10.03 & 10.40 & 11.19 & 11.75 & 12.35 & 13.55 & $\hat{\mathrm{Y}}=10.038889+0.023169 * \mathrm{CP}$ & 0.78 \\
\hline FE of DM $(\mathrm{g} \mathrm{DM} / \mathrm{h})$ & 0.302 & 0.285 & 0.269 & 0.253 & 0.236 & 25.78 & $\hat{\mathrm{Y}}=0.302156-0.000234 * \mathrm{CP}$ & 0.62 \\
\hline $\mathrm{FE}$ of NDF $(\mathrm{g} \mathrm{NDF} / \mathrm{h})$ & 104.53 & 112.03 & 110.02 & 115.30 & 108.13 & 27.15 & $\hat{\mathrm{Y}}=110.0^{\mathrm{ns}}$ & - \\
\hline RUE of DM (g DM/h) & 177.68 & 181.47 & 160.71 & 151.31 & 152.38 & 28.14 & $\hat{\mathrm{Y}}=164.71^{\mathrm{ns}}$ & - \\
\hline RUE of NDF (g NDF/h) & 66.19 & 71.04 & 67.88 & 65.65 & 69.25 & 29.21 & $\hat{\mathrm{Y}}=68.0^{\mathrm{ns}}$ & - \\
\hline
\end{tabular}

* Significant at 1 and $5 \%$ by the t-test, respectively.

ns - not significant; CP - crude protein; FE - feeding efficiency; RUE - rumination efficiency; $\mathrm{LW}^{0.75}$ - metabolic weight.

Table 4 - Number of chews per sheep fed cactus pear in substitution of corn in the diet

\begin{tabular}{|c|c|c|c|c|c|c|c|c|}
\hline \multirow{2}{*}{ Variable } & \multicolumn{5}{|c|}{ Cactus pear levels (g of DM/kg) } & \multirow{2}{*}{ CV $(\%)$} & \multirow{2}{*}{ Regression equation } & \multirow{2}{*}{$\mathrm{r}^{2}$} \\
\hline & 0 & 70 & 140 & 210 & 280 & & & \\
\hline No. of ruminated boli/day & 276.34 & 214.88 & 259.08 & 249.71 & 211.26 & 15.31 & $\hat{\mathrm{Y}}=242.25^{\mathrm{ns}}$ & \\
\hline No. of chews/day & 12777 & 13857 & 16412 & 15328 & 16040 & 14.46 & $\hat{\mathrm{Y}}=12844.03+11.41497 * \mathrm{CP}$ & 0.68 \\
\hline No. ruminating chews/bolus & 46.22 & 64.48 & 63.34 & 61.38 & 75.94 & 38.03 & $\hat{\mathrm{Y}}=62.272^{\mathrm{ns}}$ & - \\
\hline
\end{tabular}


The number of chews per day (12,777 chews/day) of sheep that did not receive cactus pear (treatment with $280 \mathrm{~g} / \mathrm{kg}$ DM corn) was due to the lower amount of dietary NDF (426 vs $481.2 \mathrm{~g} / \mathrm{kg}$ for the diet with $280 \mathrm{~g} / \mathrm{kg} \mathrm{DM}$ of cactus pear) and consequently lower content of dietary peNDF (physically effective NDF). Beauchemin \& Yang (2005) reported that by decreasing the peNDF content of the diets, the number of chews per day during intake was linearly reduced and tended to reduce the number of chews during rumination.

Factors such as the NDF content of cactus pear above that of corn $(311.6 v s .114 .4 \mathrm{~g} / \mathrm{kg}$ ), particle size of the cactus offered to the animals, physical quantities of fresh food intake, and roughage; concentrate ratio (40:60), in which only Tifton hay promoted an average consumption of at least $420 \mathrm{~g}$ /day of NDF, contributed to the increase in NCD. It is noteworthy that the association of cactus pear with the roughage, which is a highly effective source of fiber, is necessary for the maintenance of normal rumen conditions and prevention of metabolic disorders, as recommended by Mattos et al. (2000).

The digestibility coefficients of DM, OM, CP, and NDF increased linearly with increasing levels of cactus pear in the diet (Figure 1). The OM digestibility ranged from 733.7 to $832 \mathrm{~g} / \mathrm{kg}$, and the intake of digestible organic matter was $0.851,0.973,1.067,0.988$ and $0.990 \mathrm{~kg} / \mathrm{day}$ for each cactus pear treatment $(0,70,140,210$ and $280 \mathrm{~g} / \mathrm{kg}$ of DM), respectively.

Similarly, the CP digestibility ranged from 745.3 to $866.2 \mathrm{~g} / \mathrm{kg}$, representing digestible protein intakes of 154.3, 180.7, 192.8, 180.7 and $174.8 \mathrm{~g}$ /day for each treatment, respectively. There were no associative effects; the digestibility of nutrients increased with the inclusion of cactus pear forage in the diets.

Digestible organic matter is important for ruminal microbial protein synthesis as an energy source. From the digestible protein intake, it is estimated that the $\mathrm{N}$

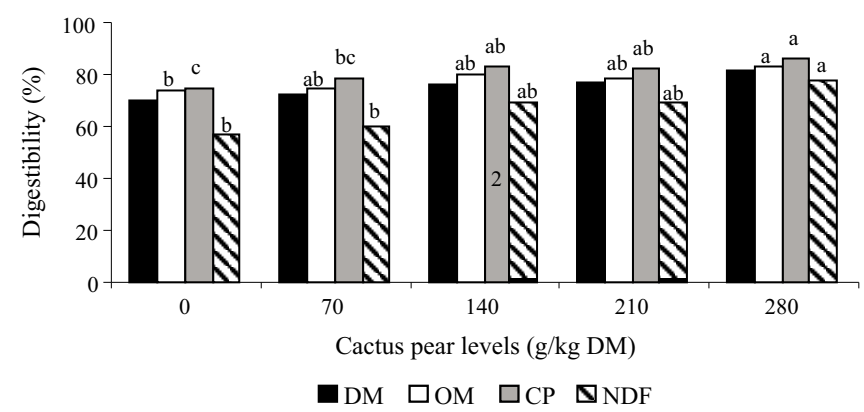

Figure 1 - Nutrient digestibility by Santa Inês sheep fed cactus pear (Opuntia ficus indica Mill) in substitution of corn. intakes were $24.7,28.9,30.8,28.9$ and $27.9 \mathrm{~g}$ /day for each treatment, respectively. Nitrogen stimulated ruminal microbial growth, favoring cellulolytic activity.

The NDF digestibility increased linearly $(\mathrm{P}<0.001)$ with increasing levels of cactus pear in the diet. The NDF digestibility varied from 565.8 to $775.3 \mathrm{~g} / \mathrm{kg}$ between the 0 and $280 \mathrm{~g} / \mathrm{kg} \mathrm{DM}$ of cactus pear treatments, respectively. Cactus pear has high contents of soluble carbohydrates, such as pectin, which is rapidly fermented in the rumen. The neutral detergent fiber in the diets ranged from 426.0 to $481.2 \mathrm{~g} / \mathrm{kg}$ between the 0 and $280 \mathrm{~g} / \mathrm{kg}$ DM of cactus pear treatments, respectively. Most of the NDF in the diet came from Tifton hay ( $316.7 \mathrm{~g} / \mathrm{kg} \mathrm{DM})$. The combination of Tifton hay with cactus pear promoted the physical effectiveness of NDF in the diet. This fiber stimulated chewing and rumination, ensuring a suitable ruminal environment for the development of microbial populations.

In this study, no digestive disturbances causing reductions in DM intake and in the digestibility of nutrients were observed. Likewise, there were no liquid feces or increases in abdominal distension in the animals. It is assumed that ruminal $\mathrm{pH}$ was not altered by the inclusion of cactus pear forage in the diet. Misra et al. (2006) verified this when they found ruminal $\mathrm{pH}$ at around 7.0 when cactus pear was included in the diet of sheep. Ben Salem \& Smith (2008) also reported that the high content of sugars in cactus pear did not affect ruminal fermentation in sheep.

The daily weight gain (DWG) decreased linearly $(\mathrm{P}<0.05)$ with increasing addition of cactus pear in the diet (Figure 2). The decrease in the amount of energy intake in the diets with 140 and $280 \mathrm{~g} / \mathrm{kg}$ DM cactus pear reduced the weight gain of animals.

The DWG decreased from 255 to $210 \mathrm{~g}$ /day between the diets with 0 and $280 \mathrm{~g} / \mathrm{kg}$ of DM of cactus pear, respectively. The reduction of the metabolizable energy supply in the diet (2.30-2.05 Mcal of ME/kg DM) and the ME intake from the $210 \mathrm{~g} / \mathrm{kg}$ DM cactus pear treatment led

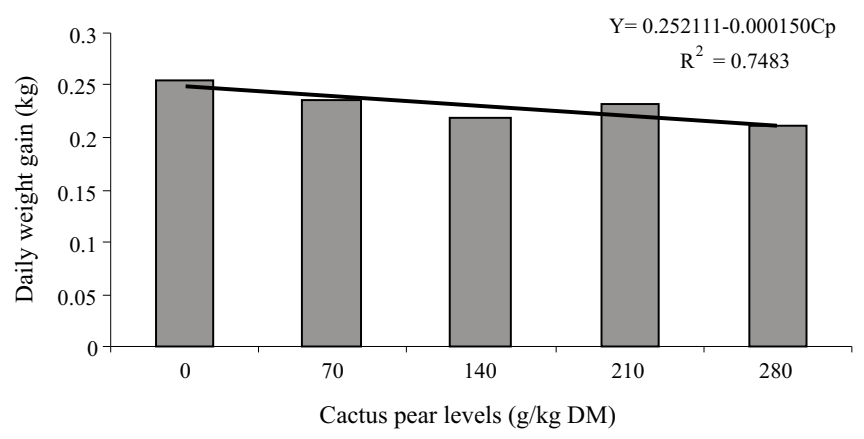

Figure 2 - Performance of Santa Inês sheep fed cactus pear (Opuntia ficus indica Mill) in substitution of corn. 
to a marginal reduction in the weight gain of sheep. It could be inferred that for each additional percentage unit of cactus pear, there was a reduction of approximately $0.378 \mathrm{~g}$ in the DWG. This difference of $45 \mathrm{~g}$ between the DWG of sheep fed diets containing 0 and $280 \mathrm{~g} / \mathrm{kg} \mathrm{DM}$ of cactus pear is considered to be relatively small. For the Brazilian semiarid region, where soil and climate conditions make the production of cereal grains such as corn difficult, the use of cactus pear forage as a substitute for this cereal in feedlot sheep is justifiable. There was a higher intake of dry matter per kg of weight gain, resulting in lower feeding efficiency (186, 177, 169, 160 and $152 \mathrm{~g} / \mathrm{kg} \mathrm{DM})$ and leading to a linear decrease $(\mathrm{P}<0.05)$ with increasing levels of cactus pear in the diet.

\section{Conclusions}

The total substitution of corn by cactus pear, despite leading to a reduction in weight gain, increased the DM intake and improved the ability of sheep to digest the nutrients. Cactus pear is thus recommended as part of the diet during the finishing of feedlot sheep in Brazilian semiarid regions.

\section{References}

ALBRIGHT, J.L. Nutrition, feeding and calves: feeding behavior of dairy cattle. Journal of Dairy Science, v.76, n.2, p.458-498, 1993.

ARNAUD, B.L.; VÉRAS, A.S.C.; FERREIRA, M.A. et al. Efeitos da substituição do feno de capim-tifton e do farelo de milho pela palma forrageira e pelo farelo de soja sobre a ingestão de alimentos e parâmetros fisiológicos. Acta Scientiarum. Animal Sciences, v.27, n.4, p.475-482, 2005.

BEAUCHEMIN, K.A.; YANG, W.Z. Effects of physically effective fiber on intake, chewing activity, and ruminal acidosis for dairy cows fed diets based on corn silage. Journal of Dairy Science, v.88, p.2117-2129, 2005.

BEN SALEM, H.; SMITH, T. Feeding strategies to increase small ruminant production in dry environments. Small Ruminant Research, v.77, p.174-194, 2008.

BURGER, P.J.; PEREIRA, J.C.; QUEIROZ,A.C. et al. Comportamento ingestivo em bezerros holandeses alimentados com dietas contendo diferentes níveis de concentrado. Revista Brasileira de Zootecnia, v.29, n.1, p.236-242, 2000.

CARDOSO, A.R.; CARVALHO, S.; GALVANI, D.B. et al. Comportamento ingestivo de cordeiros alimentados com dietas contendo diferentes níveis de fibra em detergente neutro. Ciência Rural, v.36, n.2, p.604-609, 2006.

CARVALHO, S.; RODRIGUES, M.T.; BRANCO, R.H. et al. Comportamento ingestivo de cabras Alpinas em lactação alimentadas com dietas contendo diferentes níveis de fibra em detergente neutro proveniente da forragem. Revista Brasileira de Zootecnia, v.35, n.2, p.562-568, 2006.

CASALI, A.O.; DETMANN, E.; VALADARES FILHO, S.C. et al. Influência do tempo de incubação e do tamanho de partículas sobre os teores de compostos indigestíveis em alimentos e fezes bovinas obtidos por procedimentos in situ. Revista Brasileira de Zootecnia, v.37, n.2, p.335-342, 2008.
COSTA, R.G.; TREVIÑO, I.H.; MEDEIROS, G.R. et al. Effects of replacing corn with cactus pear (Opuntia ficus indica Mill) on the performance of Santa Inês lambs. Small Ruminant Research, v.102, p.13-17, 2012.

FELKER, P. Produção e utilização de forragem. In: BARBERA, G.; INGLESE, P.; BARRIOS, E.P. (Eds). Agroecologia cultivo e usos da palma forrageira, estudo da FAO em produção e proteção vegetal. Paraíba: SEBRAE-PB/FAO, 2001. p.147-157. (Estudo da FAO em Produção e Proteção Vegetal, 132).

FERREIRA, M.A. Palma forrageira na alimentação de bovinos leiteiros. Recife: UFRPE, Imprensa Universitária, 2005. 68p.

HALL, M.B.; HOOVER, W.H.; JENNINGS, J.P. et al. A method for partitioning neutral detergent-soluble carbohydrates. Journal of the Science of Food Agriculture, v.79, n.15, p.2079-2086, 1999.

LIMA, R.M.B.; FERREIRA, M.A.; BRASIL, L.H.A. et al. Substituição do milho por palma forrageira: comportamento ingestivo de vacas mestiças em lactação. Acta Scientiarum Animal Sciences, v.25, n.2, p.347-353, 2003.

MARTIN, P.; BATESON, P. Measuring behavior: An introductory guide. 2.ed. United Kingdom: Cambridge University Press, 1993. $222 \mathrm{p}$.

MATTOS, L.M.E.; FERREIRA, M.A.; SANTOS, D.C. et al. Associação da palma forrageira (Opuntia ficus indica Mill) com diferentes fontes de fibra na alimentação de vacas $5 / 8$ HolandêsZebu em lactação. Revista Brasileira de Zootecnia, v.29, n.6, p.2128-2134, 2000 (supl. 1).

MELO, A.A.S.; FERREIRA, M.A.; CHAVES, A.S. et al. Substituição parcial do farelo de soja por uréia e palma forrageira (Opuntia fícus indica Mill) em dietas para vacas em lactação. I. Desempenho. Revista Brasileira de Zootecnia, v.32, n.3, p.727-736, 2003.

MENDOÇA, S.S.; CAMPOS, J.M.S.; VALADARES FILHIO, S.C. Comportamento ingestivo de vacas leiteras alimentadas com dietas à base de cana-de-açúcar ou silagem de milho. Revista Brasileira de Zootecnia, v.33, n.3, p.723-728, 2004.

MENEZES, C.M.D.C.; SCHWALBACH, L.M.J.; COMBRINCK, W.J. et al. Effects of sun-dried Opuntia ficus-indica on feed and water intake and excretion of urine and faeces by Dorper sheep. South African Journal of Animal Science, v.40, n.5, p.491-494, 2010 (Supp. 1).

MISRA, A.K.; MISHRA, A.S.; TRIPATHI, M.K. et al. Intake, digestion and microbial protein synthesis in sheep on hay supplemented with prickly pear cactus (Opuntia ficus-indica Mill) with or without groundnut meal. Small Ruminant Research, v.63, p.125-134, 2006.

NATIONAL RESEARCH COUNCIL - NRC. Nutrient requeriments of sheep. 6.ed. Washington, D.C.: National Academy Press, 1985. 99p.

POLLI, V.A.; RESTLE, J.; SENNA, D.B. et al. Aspectos relativos à ruminação de bovinos e bubalinos em regime de confinamento. Revista da Sociedade Brasileira de Zootecnia, v.25, n.5, p.987-993, 1996.

QUEIROZ, A.C.; NEVES, J.S.; MIRANDA, L.F. et al. Efeito do nível de fibra e da fonte de proteína sobre o comportamento alimentar de novilhas mestiças Holandês-Zebu. Arquivo Brasileiro de Medicina Veterinária e Zootecnia, v.53, n.1, p.84-88, 2001.

SANTOS, M.V.F.; FARIAS, I.; LIRA, M.A. et al. Colheita da palma forrageira (Opuntia ficus indica Mill) cv. Gigante sobre o desempenho de vacas em lactação. Revista Brasileira de Zootecnia, v.27, n.1, p.33-39, 1998.

SILVA, D.J.; QUEIROZ, A.C. Análise de alimentos: métodos químicos e biológicos. 3.ed. Viçosa, MG: UFV, 2002. 235p.

SNIFFEN, C.J.; O'CONNOR, J.D.; VAN SOEST, P.J. et al. A net carbohydrate and protein system for evaluating cattle diets: II. Carbohydrate and protein availability. Journal of Animal Science, v.70, n.3, p.3562-3577, 1992.

TEGEGNE, F. Valor nutricional de Opuntia ficus-indica como forraje de rumiantes en Etiópia. In: MONDRAGÓN-JACOBO, C.; PÉREZ-GONZÁLEZ, S. (Eds.) El nopal (Opuntia spp.) como 
forraje. Roma: FAO, 2003. p.113-122. (Estudio FAO - Producción y Protección Vegetal, 169).

TEGEGNE, F.; KIJORA, C.; PETERS K.J. Study on the optimal level of cactus pear (Opuntia ficus-indica) supplementation to sheep and its contribution as source of water. Small Ruminant Research, v.72, p.157-164, 2007.

TEIXEIRA, J.C.; EVANGELISTA, A.R.; PEREZ, J.R.O. et al. Cinética da digestão ruminal da palma forrageira (Nopalea cochenillifera (1.) Lyons-cactaceae) em bovinos e caprinos. Ciência e Agrotecnologia, v.23, n.1, p.179-186, 1999.
VAN SOEST, P.J. Nutritional ecology of the ruminant. 2.ed. Ithaca: Cornell University Press, 1994. 476p.

VAN SOEST, P.J.; ROBERTSON, J.B.; LEWIS, B.A. Methods for dietary fiber, neutral detergent fiber, and nonstarch polysaccharides in relation to animal nutrition. Journal of Dairy Science, v.74, p.3583-3597, 1991.

WEISS, W.P. Energy prediction equations for ruminant feeds. In: CORNELL NUTRITION CONFERENCE FEED MANUFACTURES, 61., 1999. Proceedings... Ithaca: Cornell University, 1999. p.176-185. 